\title{
Hydrochemistry and Application of GIS in Groundwater Quality in Nagalapura Taluk, Bellary District, Karnataka, India
}

\author{
Maradi Sangrama Nayaka*, T. Suresh*, S. Manjappa** and B. Suresh***† \\ *Department of Chemistry, Vijayanagara Sri Krishnadevaraya University, Bellary-583104, Karnataka, India \\ **Department of Chemistry, University BDT College of Engineering, Davangere-577005, Karnataka, India \\ ***Department of Civil Engineering, Bapuji Institute of Engineering \& Technology, Davangere-577 005, \\ Karnataka, India \\ $†$ Corresponding author: B. Suresh; drbssmg@gmail.com; drbssmg@bietdvg.edu
}

\author{
Nat. Env. \& Poll. Tech. \\ Website: www.neptjournal.com \\ Received: 18-05-2021 \\ Revised: 23-06-2021 \\ Accepted: 04-07-2021 \\ Key Words: \\ Groundwater quality, \\ Gibbs graphs \\ Wilcox diagram \\ GIS \\ Pollution \\ Drinking water source
}

\begin{abstract}
The assessment of groundwater quality is essential for the conservation of natural resources. Hence, this study aims to assess the hydrochemistry of groundwater in and around the Nagalapura Taluk in Bellary district, Karnataka, India. The groundwater quality variables are mapped using a Geographic Information System (GIS). For the hypothesis, the mean value of ten groundwater quality variables was obtained from 50 bore well samples (2016-2018). To assess the lead ions and type of water, the USSL, SAR, and Na\% were measured. Ionic ratio and Gibbs graphs were used to demonstrate the chemical reactions in the water samples. ArcGIS was used for spatial analysis of the quality variables. The results showed the order of $\mathrm{Cl}^{-}>\mathrm{SO}_{4}{ }^{2-}>\mathrm{HCO}_{3}{ }^{-}$with water types $\mathrm{Na}^{+}-\mathrm{Cl}^{-}$and $\mathrm{Cl}^{-}$, and the order of $\mathrm{Na}^{+}>\mathrm{Mg}^{++}>\mathrm{Ca}^{++}>\mathrm{K}^{+}$with $\mathrm{Na}^{+}$and $\mathrm{Mg}^{++}$as the dominant anion and cation, respectively. The hydrochemistry of groundwater is determined by the geological structure in 64 percent of the water samples examined. The Wilcox diagram shows that no-alkali exposure to the crops is expected. Forty one samples (82\%) fit within the C3-S1 group; this category is fit for irrigational needs. Only 01 and 03 samples showed maximum SAR during two seasons like pre-monsoon and post-monsoon periods. The maps showed that groundwater in the selected sites is usually of higher quality, whereas the presence of dolomite indicates a reduction in water quality.
\end{abstract}

\section{INTRODUCTION}

Groundwater is the water present beneath Earth's surface in rock and soil pore spaces and the fractures of rock formations (Freeze 1979). Water enters the ground in the lower layer where the discharge ends, which contains wells, springs, rivers, lakes, and the ocean. The world's freshwater supply contains $62 \%$ groundwater, which is $0.65 \%$ of the total amount of water on Earth (EPA 2009). Man-made activities on land, land use, changes in the soil layer, and ground-water percolation impact the quality of groundwater. Although groundwater testing and drilling, which includes strata analysis, are good methods for determining the depth of the aquifer and the ideal site for a bore-well, they take time and often require skilled manpower (Madan et al. 2010, Mukherjee et al. 2012, Mallick et al. 2015). On the other hand, using GIS, remote sensing, and satellite images to assess groundwater resources is beneficial and cost-effective (Adiat et al. 2012, Verma \& Singh 2013). Honarbakhsh et al. (2019) used a GIS-based approach with the Groundwater Quality Index (GWQI) to analyze groundwater quality in Marvdasht located in the semi-arid region of Iran. For this purpose, they used groundwater quality data that were collected in a five-year period (2010-2015). During the study period, the groundwater quality index (GWQI) indicated that only $3 \%$ of the total area $\left(10 \mathrm{~km}^{2}\right)$ was of low quality. $\mathrm{Mg}^{++}$, total hardness $(\mathrm{TH})$, and $\mathrm{Na}+$ were predicted to be the most sensitive water quality variables. Elubid et al. (2019) reported the spatial distribution of groundwater quality parameters in some parts of Gedare State by using GIS and the total water quality index (TWQI). Major cations and anions were found in 38 bore wells identified in this study. Furthermore, the groundwater quality is controlled by sodium and bicarbonate ions that defined the composition of the water type to be $\mathrm{Na}-\mathrm{HCO}_{3}$.

Furthermore, as reported by Hemant and Limaye (2012), Kesari et al. (2016), and Madan et al. (2010) in several parts of India, groundwater quality is deteriorating due to massive industrial effluent dumping and mining activities. The reduction in precipitation in arid places leads to an increase in the public's use of water for drinking and irrigation purposes (Mallick et al. 2015). Groundwater resources can be defined as the only vital and alternative resource for the people in dry 
areas, particularly to encourage human life through agriculture activities. With the above literature review, the present work is undertaken to generate groundwater level zonation image-based thematic maps utilizing remote sensing and GIS for improved groundwater resource utilization, planning, and management.

Seasonal maps are used to evaluate field experts' opinions and data analysis. Several experiments to assess the quality and hydrochemistry of groundwater were conducted in and around Nagalapura Taluk, Bellary district, using Pie, Schoeller, and Piper diagrams, as well as maps, to assess groundwater quality in and around Nagalapura Taluk.

\section{MATERIALS AND METHODS}

\section{Geology of Hospet, India}

Geologically, rocks of granodiorite and granite are associated with iron and manganese ore bands. These rocks are joined and intruded by doleritic dykes. Unlike hard rocks, which are partially weathered up to 5 meters below the surface, schist and phyllite can weather up to 20 meters deep.

\section{Experimental Work}

The groundwater samples obtained from twenty-five different locations in and around the Nagalapura taluk were examined and analyzed and interpreted for this study. The sampling locations in this study were identified in five different zones of the city, and groundwater samples were taken. In a GIS model, interpretation strategies that integrate ground-based and remote sensing data are developed. Critical steps include acquiring all relevant data, processing, and constructing the database. Capacity levels and data are required in assessing the study area to generate GIS data. Geologic, hydrologic, topographic, vegetation, and soil maps are among the data types available, and so are satellite imagery, geological logs, bore well locations with latitude and longitude, and hydrological data such as water quality, aquifer test data, and reports from local and regional study areas.

\section{Collection of Samples}

Groundwater samples are collected in five-liter plastic cans that have been washed and rinsed twice with distilled water. All samples were carried to the laboratory using ice-boxes and kept refrigerated at $4^{\circ} \mathrm{CAPHA}, 2005$. The Fig. 1 gives the sampling location map and details of the locations are given in Table 1. Samples were analyzed for physico-chemical variables, using respective methods as per APHA, 2005. Statistical analysis was also applied to the results and tabulated.

\section{RESULTS AND DISCUSSION}

According to preliminary research, Nagaralapura district provided the best opportunity to collect the most relevant data across the study area. 50 bore wells were chosen from a GPS field survey of the study area, and water samples were collected from these 50 locations. Hydrochemistry and all other data have been entered into the GIS. The spatial pattern of various water quality variables is discussed in this paper. During the present investigation, thematic map hardness of groundwater revealed that $80 \%$ of the groundwater samples in the pre-monsoon period, $76 \%$ of the groundwater samples during the monsoon period, and $75 \%$ of the groundwater samples during the post-monsoon period had hardness in the range of 300 to $600 \mathrm{mg} . \mathrm{L}^{-1}$. During the pre-monsoon season, $6 \%$ of the groundwater samples (Fig. 2(a)), $5 \%$ of the groundwater samples during monsoon (Fig. 2(b)) and $4 \%$ of the groundwater samples during the post-monsoon period (Fig. 2(c)) had hardness less than $300 \mathrm{mg} . \mathrm{L}^{-1}$ (Hemant $\&$ Limaye 2012). It was observed that $28 \%$ and $22 \%$ of the groundwater samples during pre- and post-monsoon periods had hardness above $600 \mathrm{mg} . \mathrm{L}^{-1}$. In both seasons, it was evident that more than $20 \%$ of the groundwater samples exceeded the permissible limit set by BIS and WHO drinking water standards. The hardness of water is caused due to occurrence of carbonates and bi-carbonates of $\mathrm{Ca}^{++}$and $\mathrm{Mg}^{++}, \mathrm{Cl}^{-}, \mathrm{NO}_{3}^{-}$, and $\mathrm{SO}_{4}{ }^{2-}$ of $\mathrm{Ca}^{++}$and $\mathrm{Mg}^{++}$. The maximum content of $\mathrm{TH}$ was found in HW-41 (M.M.Halli near Anjinappa home), which is above the permissible limit. Most of the selected locations had TH content within the permissible limit. Spatial distribution of TH during pre- and post-monsoon periods, and monsoon periods are given in Fig. 2(a), 2(b), and 2(c) respectively.

Maximum hardness was observed at HW-41 (M.M.Halli near Anjinappa home) (1280 mg. $\left.\mathrm{L}^{-1}\right)$ in all the seasons during the study period, while it was $143 \mathrm{mg} . \mathrm{L}^{-1}$ in HW-43 (D.N.Keri Devalapura near Shayari Durugamma Temple) during post-monsoon and monsoon periods. However, it was $195 \mathrm{mg} . \mathrm{L}^{-1}$ in HW-42 (D.N.Keri near Nandibanda) during the pre-monsoon season. Pujari, et al. (2012) recorded $\mathrm{TH}$ of $808 \mathrm{mg} . \mathrm{L}^{-1}$ during the rainy season in Kovaya, the coastal area of Gujarat whereas Champidi et al. (2011) recorded $1685 \mathrm{mg} . \mathrm{L}^{-1}$ of $\mathrm{TH}$ in the Erasinos area of eastern Attica.

The perusal map of the $\mathrm{Ca}^{++}$content showed that $82 \%$ and $81 \%$ of groundwater samples have calcium concentrations in the range of $75 \mathrm{mg} . \mathrm{L}^{-1}$ to $200 \mathrm{mg} . \mathrm{L}^{-1}$ during pre- and post-monsoon periods, and monsoon periods. 
Table 1: Location of the bore-well samples in the Hospet Taluk, Bellary District.

\begin{tabular}{|c|c|c|c|c|c|c|c|}
\hline Sl. No. & Village & location & $\begin{array}{l}\text { Latitude and } \\
\text { Longitude }\end{array}$ & Sl. No. & Village & Location & $\begin{array}{l}\text { Latitude and } \\
\text { Longitude }\end{array}$ \\
\hline HW-1 & Hossur & Kichadi Net & $\begin{array}{l}15^{0} 16^{\prime} 08.20 \mathrm{~N} \\
76^{0} 23^{\prime} 26.82 \mathrm{E}\end{array}$ & HW-26 & Bylavaddigeri & Dharmasagara & $\begin{array}{l}15^{0} 14^{\prime} 55.55 \mathrm{~N} \\
76^{0} 31^{\prime} 53.64 \mathrm{E}\end{array}$ \\
\hline HW-2 & Hossur & $\begin{array}{l}\text { Near Railway } \\
\text { Gate }\end{array}$ & $\begin{array}{l}15^{0} 16^{\prime} 08.10 \mathrm{~N} \\
76^{0} 23^{\prime} 26.50 \mathrm{E}\end{array}$ & HW-27 & Bylavaddigeri & Kakubalu & $\begin{array}{l}15^{0} 14^{\prime} 55.43 \mathrm{~N} \\
76^{0} 31^{\prime} 53.60 \mathrm{E}\end{array}$ \\
\hline HW-3 & Nagenahalli & Nagenahalli & $\begin{array}{l}15^{0} 17^{\prime} 50.23 \mathrm{~N} \\
76^{0} 24^{\prime} 12.59 \mathrm{E}\end{array}$ & HW-28 & P K Halli & Ganesh Tample & $\begin{array}{l}15^{0} 16^{\prime} 22.58 \mathrm{~N} \\
76^{0} 28^{\prime} 37.77 \mathrm{E}\end{array}$ \\
\hline HW-4 & Nagenahalli & Basavadurga & $\begin{array}{l}15^{0} 17^{\prime} 50.17 \mathrm{~N} \\
76^{0} 24^{\prime} 12.30 \mathrm{E}\end{array}$ & HW-29 & P K Halli & Ingalagiri & $\begin{array}{l}15^{0} 16^{\prime} 22.17 \mathrm{~N} \\
76^{0} 28^{\prime} 37.41 \mathrm{E}\end{array}$ \\
\hline HW-5 & Kamalapaura & $\begin{array}{l}\text { Opp SriKari } \\
\text { College }\end{array}$ & $\begin{array}{l}15^{0} 18^{\prime} 21.53 \mathrm{~N} \\
76^{0} 28^{\prime} 27.34 \mathrm{E}\end{array}$ & HW-30 & P K Halli & P K Halli & $\begin{array}{l}15^{0} 16^{\prime} 22.38 \mathrm{~N} \\
76^{0} 28^{\prime} 37.52 \mathrm{E}\end{array}$ \\
\hline HW-6 & $\begin{array}{l}\text { Seetharam } \\
\text { Tanda }\end{array}$ & $\begin{array}{l}\text { Seetharam } \\
\text { Tanda Cross }\end{array}$ & $\begin{array}{l}15^{0} 16^{\prime} 30.48 \mathrm{~N} \\
76^{0} 24^{\prime} 15.63 \mathrm{E}\end{array}$ & HW-31 & $\begin{array}{l}\text { Hosapete (T B } \\
\text { Dam) }\end{array}$ & $\begin{array}{l}\text { Muttumariyamma } \\
\text { Temple }\end{array}$ & $\begin{array}{l}15^{0} 16^{\prime} 27.64 \mathrm{~N} \\
76^{0} 21^{\prime} 10.28 \mathrm{E}\end{array}$ \\
\hline HW-7 & $\begin{array}{l}\text { Seetharam } \\
\text { Tanda }\end{array}$ & Mustafa Darga & $\begin{array}{l}15^{0} 16^{\prime} 30.17 \mathrm{~N} \\
76^{0} 24^{\prime} 15.10 \mathrm{E}\end{array}$ & HW-32 & Hosapate & Industrial Area & $\begin{array}{l}15^{0} 16^{\prime} 27.81 \mathrm{~N} \\
76^{0} 21^{\prime} 10.40 \mathrm{E}\end{array}$ \\
\hline HW-8 & $\begin{array}{l}\text { Seetharam } \\
\text { Tanda }\end{array}$ & N R Camp & $\begin{array}{l}15^{0} 16^{\prime} 30.22 \mathrm{~N} \\
76^{0} 24^{\prime} 15.30 \mathrm{E}\end{array}$ & HW-33 & Hosapete & $\begin{array}{l}\text { Sanaki veerabadra } \\
\text { temple }\end{array}$ & $\begin{array}{l}15^{0} 16^{\prime} 27.79 \mathrm{~N} \\
76^{0} 21^{\prime} 10.38 \mathrm{E}\end{array}$ \\
\hline HW-9 & Bukkasagara & $\begin{array}{l}76 \text { Venkarta- } \\
\text { pura }\end{array}$ & $\begin{array}{l}15^{0} 21^{\prime} 03.28 \mathrm{~N} \\
76^{0} 31^{\prime} 50.64 \mathrm{E}\end{array}$ & HW-34 & Hosapete & $\begin{array}{l}\text { Chittavadigeppa } \\
\text { temple }\end{array}$ & $\begin{array}{l}15^{0} 16^{\prime} 27.75 \mathrm{~N} \\
76^{0} 21^{\prime} 10.26 \mathrm{E}\end{array}$ \\
\hline HW-10 & Bukkasagara & $\begin{array}{l}\text { Near Anjaneya } \\
\text { Temple }\end{array}$ & $\begin{array}{l}15^{0} 21^{\prime} 03.36 \mathrm{~N} \\
76^{0} 31^{\prime} 50.22 \mathrm{E}\end{array}$ & HW-35 & Kallahalli & Vyasanakere Station & $\begin{array}{l}15^{0} 13^{\prime} 05.08 \mathrm{~N} \\
76^{0} 24^{\prime} 14.94 \mathrm{E}\end{array}$ \\
\hline HW-11 & Bukkadagara & SC-ST Keri & $\begin{array}{l}15^{0} 21^{\prime} 03.14 \mathrm{~N} \\
76^{0} 31^{\prime} 50.10 \mathrm{E}\end{array}$ & HW-36 & Kallahalli & Kaniverayan Gudi & $\begin{array}{l}15^{0} 13^{\prime} 05.29 \mathrm{~N} \\
76^{0} 24^{\prime} 14.82 \mathrm{E}\end{array}$ \\
\hline HW-12 & Ramasagara & $\begin{array}{l}\text { near Renu- } \\
\text { kamma House }\end{array}$ & $\begin{array}{l}15^{0} 16^{\prime} 03.02 \mathrm{~N} \\
76^{0} 23^{\prime} 04.68 \mathrm{E}\end{array}$ & HW-37 & Kallhalli & Jambaiah Hola & $\begin{array}{l}15^{0} 13^{\prime} 05.31 \mathrm{~N} \\
76^{0} 24^{\prime} 14.41 \mathrm{E}\end{array}$ \\
\hline HW-13 & Ramasagara & $\begin{array}{l}\text { near Shi- } \\
\text { vamurthy } \\
\text { House) }\end{array}$ & $\begin{array}{l}15^{0} 16^{\prime} 03.20 \mathrm{~N} \\
76^{0} 23^{\prime} 04.41 \mathrm{E}\end{array}$ & HW-38 & Danaapura & $\begin{array}{l}\text { Galemma temple } \\
\text { Hola }\end{array}$ & $\begin{array}{l}15^{0} 19^{\prime} 29.73 \mathrm{~N} \\
76^{0} 35^{\prime} 32.63 \mathrm{E}\end{array}$ \\
\hline HW-14 & Sanaapura & $\begin{array}{l}\text { near Narasim- } \\
\text { ha House }\end{array}$ & $\begin{array}{l}15^{0} 16^{\prime} 03.36 \mathrm{~N} \\
76^{0} 23^{\prime} 04.22 \mathrm{E}\end{array}$ & HW-39 & Danaapura & Hampinkatte & $\begin{array}{l}15^{0} 19^{\prime} 29.52 \mathrm{~N} \\
76^{0} 35^{\prime} 32.38 \mathrm{E}\end{array}$ \\
\hline HW-15 & Sanaapura & $\begin{array}{l}\text { near Kurugo- } \\
\text { su Basappa } \\
\text { House }\end{array}$ & $\begin{array}{l}15^{0} 16^{\prime} 03.08 \mathrm{~N} \\
76^{0} 23^{\prime} 04.12 \mathrm{E}\end{array}$ & HW-40 & Danaapura & Ayyanhalli & $\begin{array}{l}15^{0} 19^{\prime} 29.81 \mathrm{~N} \\
76^{0} 35^{\prime} 32.42 \mathrm{E}\end{array}$ \\
\hline HW-16 & Devasamudra & $\begin{array}{l}\text { near Health } \\
\text { Centre }\end{array}$ & $\begin{array}{l}15^{0} 20^{\prime} 49.07 \mathrm{~N} \\
76^{0} 38^{\prime} 07.89 \mathrm{E}\end{array}$ & HW-41 & M M Halli & Anjinappa Home & $\begin{array}{l}15^{0} 09^{\prime} 29.33 \mathrm{~N} \\
76^{0} 20^{\prime} 48.93 \mathrm{E}\end{array}$ \\
\hline HW-17 & Devasamudra & $\begin{array}{l}\text { Krishna Naga- } \\
\text { ra Camp }\end{array}$ & $\begin{array}{l}15^{0} 20^{\prime} 49.28 \mathrm{~N} \\
76^{0} 38^{\prime} 07.52 \mathrm{E}\end{array}$ & HW-42 & D N Kere & Nandi Banda & $\begin{array}{l}15^{0} 35^{\prime} 41.24 \mathrm{~N} \\
76^{0} 53^{\prime} 52.60 \mathrm{E}\end{array}$ \\
\hline HW-18 & Devasamudra & Harejayagnuru & $\begin{array}{l}15^{0} 20^{\prime} 49.32 \mathrm{~N} \\
76^{0} 38^{\prime} 07.49 \mathrm{E}\end{array}$ & HW-43 & $\begin{array}{l}\text { D N Kere (De- } \\
\text { valapura) }\end{array}$ & $\begin{array}{l}\text { Shyari Durgammana } \\
\text { Gudi }\end{array}$ & $\begin{array}{l}15^{0} 35^{\prime} 41.48 \mathrm{~N} \\
76^{0} 53^{\prime} 52.77 \mathrm{E}\end{array}$ \\
\hline HW-19 & $\begin{array}{l}\text { Hampadevan- } \\
\text { ahalli }\end{array}$ & $\begin{array}{l}\text { Chikka Jaya- } \\
\text { ganuru }\end{array}$ & $\begin{array}{l}15^{0} 19^{\prime} 38.45 \mathrm{~N} \\
76^{0} 41^{\prime} 35.41 \mathrm{E}\end{array}$ & HW-44 & $\begin{array}{l}\text { D N Kere (Gol- } \\
\text { larahalli) }\end{array}$ & $\begin{array}{l}\text { near Gowdru Ven- } \\
\text { katesh House }\end{array}$ & $\begin{array}{l}15^{0} 06^{\prime} 67.54 \mathrm{~N} \\
76^{0} 22^{\prime} 20.30 \mathrm{E}\end{array}$ \\
\hline HW-20 & $\begin{array}{l}\text { Hampadevan- } \\
\text { ahalli }\end{array}$ & $\begin{array}{l}\text { Near Dugu- } \\
\text { lamma Temple }\end{array}$ & $\begin{array}{l}15^{0} 19^{\prime} 38.45 \mathrm{~N} \\
76^{0} 41^{\prime} 35.34 \mathrm{E}\end{array}$ & HW-45 & Nagalapura & Hullinamane & $\begin{array}{l}15^{0} 08^{\prime} 36.55 \mathrm{~N} \\
76^{0} 23^{\prime} 54.98 \mathrm{E}\end{array}$ \\
\hline HW-21 & Devalapura & $\begin{array}{l}\text { opp Ma- } \\
\text { hadevana } \\
\text { House }\end{array}$ & $\begin{array}{l}15^{0} 35^{\prime} 42.10 \mathrm{~N} \\
76^{0} 53^{\prime} 52.99 \mathrm{E}\end{array}$ & HW-46 & Nagalapura & Byalakundi & $\begin{array}{l}15^{0} 08^{\prime} 36.17 \mathrm{~N} \\
76^{0} 23^{\prime} 54.60 \mathrm{E}\end{array}$ \\
\hline HW-22 & Devalapura & Nallapur & $\begin{array}{l}15^{0} 35^{\prime} 42.26 \mathrm{~N} \\
76^{0} 53^{\prime} 52.54 \mathrm{E}\end{array}$ & HW-47 & $\begin{array}{l}\text { Nagalapura } \\
\text { (Gunda) }\end{array}$ & Near gowri Swami & $\begin{array}{l}15^{0} 08^{\prime} 36.24 \mathrm{~N} \\
76^{0} 23^{\prime} 54.76 \mathrm{E}\end{array}$ \\
\hline HW-23 & Gadiganuru & $\begin{array}{l}\text { Opp Mallikar- } \\
\text { juna House }\end{array}$ & $\begin{array}{l}15^{0} 12^{\prime} 24.40 \mathrm{~N} \\
76^{0} 35^{\prime} 21.35 \mathrm{E}\end{array}$ & HW-48 & Chilakanahatti & Thimlapura & $\begin{array}{l}15^{0} 04^{\prime} 33.23 \mathrm{~N} \\
76^{0} 21^{\prime} 02.73 \mathrm{E}\end{array}$ \\
\hline HW-24 & Gadiganuru & Opp Hospital & $\begin{array}{l}15^{0} 12^{\prime} 24.20 \mathrm{~N} \\
76^{0} 35^{\prime} 21.41 \mathrm{E}\end{array}$ & HW-49 & Chilakanahatti & Pootalakatte & $\begin{array}{l}15^{0} 04^{\prime} 33.17 \mathrm{~N} \\
76^{0} 21^{\prime} 02.51 \mathrm{E}\end{array}$ \\
\hline HW-25 & Bylavaddigeri & Opp Hospital & $\begin{array}{l}15^{0} 14^{\prime} 55.68 \mathrm{~N} \\
76^{0} 31^{\prime} 53.66 \mathrm{E}\end{array}$ & HW-50 & Chilakanahatti & $\begin{array}{l}\text { Ajanta Nagalinga } \\
\text { mata }\end{array}$ & $\begin{array}{l}15^{0} 04^{\prime} 33.29 \mathrm{~N} \\
76^{0} 21^{\prime} 02.61 \mathrm{E}\end{array}$ \\
\hline
\end{tabular}




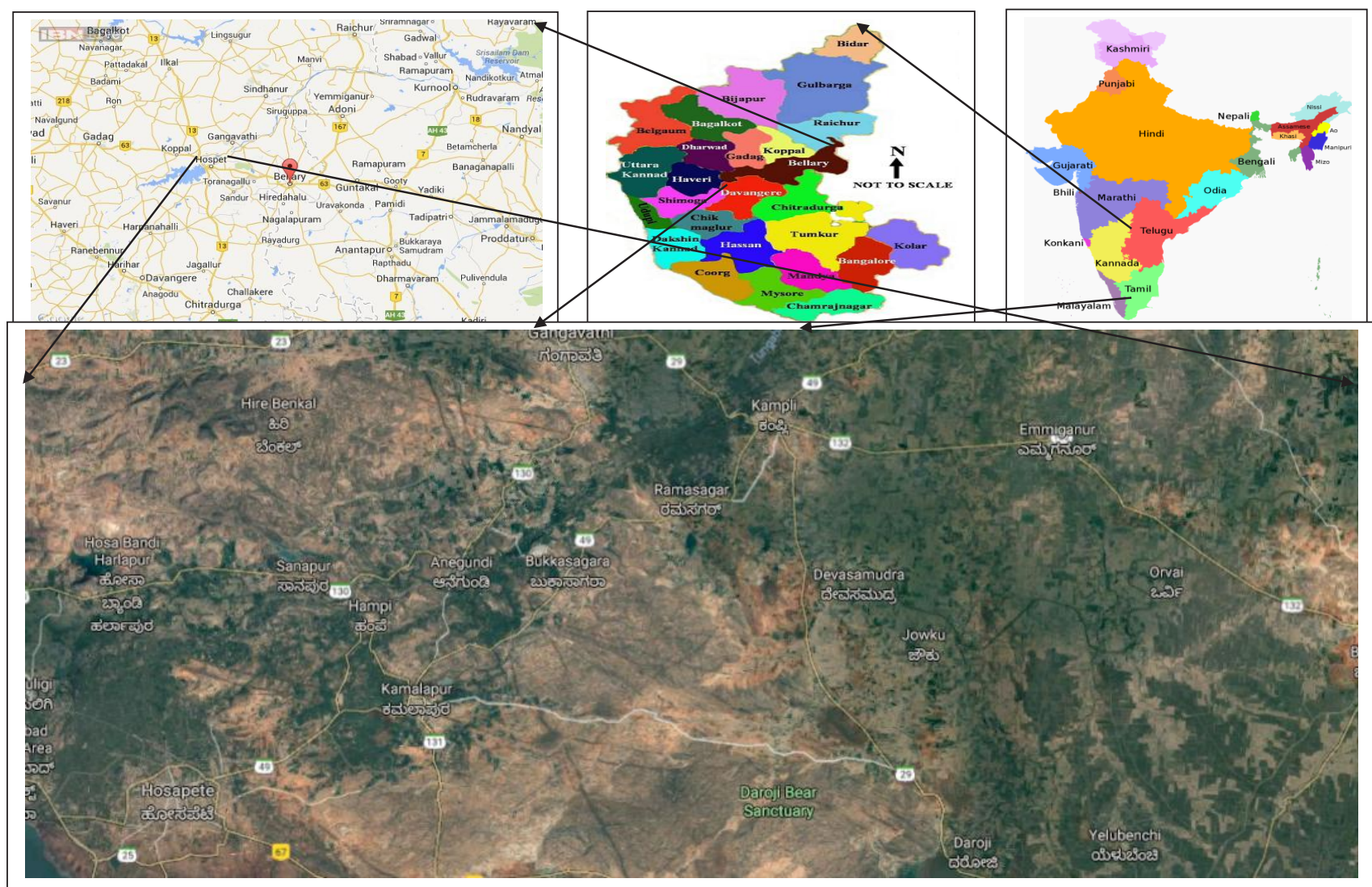

Fig. 1: Location map of the north-east of the Hospet Taluk, Bellary region.

Calcium content in the groundwater samples (Fig. 3(c)) ranged from a minimum of $40 \mathrm{mg} . \mathrm{L}^{-1}$ in HW-17 (Ramasagara near Sugandi Renukamma House) to a maximum of 412 mg. $\mathrm{L}^{-1}$ in HW-27 (Byluvaddigere near Kakubaal) during post-monsoon season. In the monsoon period (Fig. 3(b)), the calcium content ranged from a minimum of $42 \mathrm{mg} . \mathrm{L}^{-1}$ in HW-42 (D.N.Keri near Nandibanda) to a maximum of $412 \mathrm{mg} . \mathrm{L}^{-1}$ in HW-50 (Chilakanahatti near Ajatha Nagalinga Mata). In the pre-monsoon season (Fig. 3(a)), the calcium content ranged from a minimum of $20 \mathrm{mg} . \mathrm{L}^{-1}$ in HW-48 (Chilakanahatti near Thimmalapura)) to a maximum of 421 mg. $\mathrm{L}^{-1}$ in HW-27 (Byluvaddigere near Kakubaal).

The BIS permissible limit for calcium is $200 \mathrm{mg} \cdot \mathrm{L}^{-1}$. However, in the current work, $81 \%$ of the groundwater samples were within the permissible limit of drinking water guidelines of BIS. The remaining $18 \%$ of the groundwater samples in the pre-monsoon period and $17 \%$ of groundwater samples in the post-monsoon period are above the prescribed limit. The calcium content of $1 \%$ of water samples is below $75 \mathrm{mg} . \mathrm{L}^{-1}$ during three seasons (Fig. 3(a), 3(b), and 3(c)). In the present study, thematic maps of $\mathrm{Mg}^{++}$of the study area showed that $67 \%$ of pre-monsoon and $74 \%$ of post-monsoon seasons groundwater samples have magnesium concentration below $30 \mathrm{mg} . \mathrm{L}^{-1}$. $19 \%$ of the groundwater samples have magnesium content above $50 \mathrm{mg} . \mathrm{L}^{-1}$ in both seasons. The remaining samples were in the range of $30 \mathrm{mg} . \mathrm{L}^{-1}$ to $50 \mathrm{mg} . \mathrm{L}^{-1}$. This study revealed that during both seasons almost all the groundwater samples were within the permissible level and suitable for drinking purposes owing to low magnesium content. $\mathrm{Mg}^{++}$content in the assessed groundwater samples (Fig. 4(c)) ranged from a minimum of $12.6 \mathrm{mg} . \mathrm{L}^{-1}$ in HW-17 (Ramasagara (Sugandi Renukamma House) to a maximum of 153 mg. $\mathrm{L}^{-1}$ in HW-27 (Byluvaddigere near Kakubaal) during post-monsoon season. In the monsoon period in Fig. 4(b), magnesium content ranged from a minimum of $7.0 \mathrm{mg} . \mathrm{L}^{-1}$ in HW-2 (Hosuru Near Railway gate) and a maximum of 68 mg. $\mathrm{L}^{-1}$ in HW-41 (M.M.Halli near Anjinappa home). In the pre-monsoon season (Fig. 4(a)), magnesium content ranged from a minimum of $11.4 \mathrm{mg} . \mathrm{L}^{-1}$ in HW-48 (Chilakanahatti near Thimmalapura) and a maximum of $78 \mathrm{mg} . \mathrm{L}^{-1}$ in HW27 (Byluvaddigere near Kakubaal).

The spatial values in the map of the study area revealed that $1 \%$ of the groundwater samples in the pre-monsoon peri- 
od and $6 \%$ of the groundwater samples in the post-monsoon period have $\mathrm{SO}_{4}{ }^{2-}$ content less than $50 \mathrm{mg} . \mathrm{L}^{-1} .87 \%$ of the groundwater samples in the pre-monsoon period and $81 \%$ of the groundwater samples in the post-monsoon period have sulfate content in the range of $50-100 \mathrm{mg} . \mathrm{L}^{-1} .12 \%$ of the groundwater samples in the pre-monsoon period and $13 \%$ of the groundwater samples in the post-monsoon season have $\mathrm{SO}_{4}{ }^{2-}$ content more than $100 \mathrm{mg} . \mathrm{L}^{-1}$. Swarna Latha (2010) also found the same trend of $\mathrm{SO}_{4}{ }^{2-}$ concentration in her studies.

In the present study, the $\mathrm{SO}_{4}{ }^{2-}$ concentration varied between a minimum of 10.9 mg.L $\mathrm{L}^{-1}$ in HW-40 (Danapura near Iyyanahalli) to a maximum of $82 \mathrm{mg} . \mathrm{L}^{-1}$ in HW-10 (Bukkasagara (76 Venkatapura Main road near Hanuman Temple) during the post-monsoon season (Fig. 5(c)). In the monsoon season (Fig. 5(b)), the $\mathrm{SO}_{4}{ }^{2-}$ content in the groundwater samples ranged from a minimum of $9.3 \mathrm{mg} . \mathrm{L}^{-1}$ in HW-40 (Danapura near Iyyanahalli) and a maximum of 84 mg.L. $\mathrm{L}^{-1}$ in HW-10 (Bukkasagara (76 Venkatapura Main road near Hanuman Temple). In the post-monsoon period (Fig. $5(\mathrm{a}))$, the $\mathrm{SO}_{4}{ }^{2-}$ content in the groundwater samples ranged from a minimum of $8.9 \mathrm{mg} . \mathrm{L}^{-1}$ in HW-40 (Danapura near Iyyanahalli) and a maximum of $83 \mathrm{mg} . \mathrm{L}^{-1}$ in HW-10 (Bukkasagara (76 Venkatapura Main road near Hanuman Temple).

Agricultural Indices that were adopted in the present study are $\mathrm{SH}, \mathrm{MC}, \mathrm{Na}^{+}$, SAR, RSC and PI, Gibbs class I and II (anion and cation) ratio, which are relevant variables for assessing the suitability of groundwater for agricultural purposes. The irrigation indicators are adopted to categorize ground-water quality into excellent to unfit. Equations for the various hazards are adapted from Asante-Annor et al. (2018).

A salinity hazard is a major constituent of irrigation water quality that reflects crop growth and yields. The SAR values using the USSL diagram show that all the samples have less SAR value. Out of 50 samples, 03, 04, and 03 samples come under the C1-S1 category; 33, 35, and 25 samples come under the $\mathrm{C} 2$-S1 category in pre-monsoon, monsoon, and post-monsoon periods. Correspondingly 08, 06, and 04 samples come under the C1-S2 category; and 05, 06, and 12 samples come under the C2-S2 category (Fig. 3). The C3-S1 group in the USSL diagram (Fig. 6) is considered as a moderate water category for irrigation. These imply that

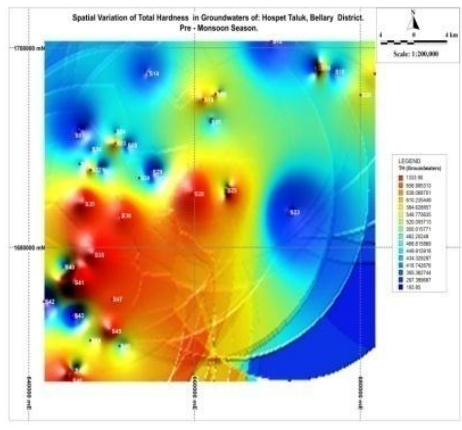

Fig. 2(a):

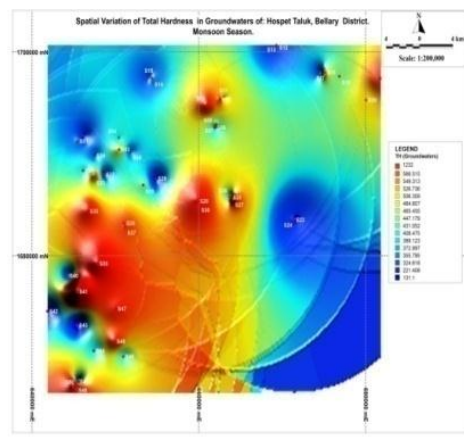

Fig. 2(a):

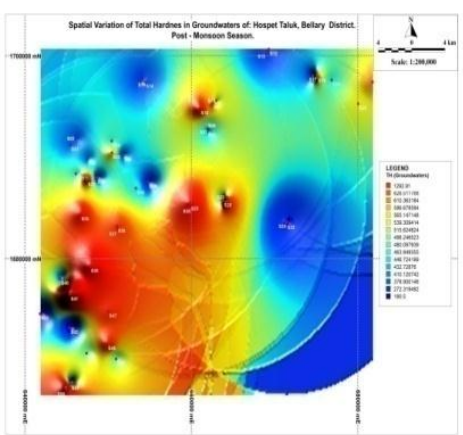

Fig. 2(a):

Average of three seasons level of TH (mg/L) at selected areas of Hospet Taluk.

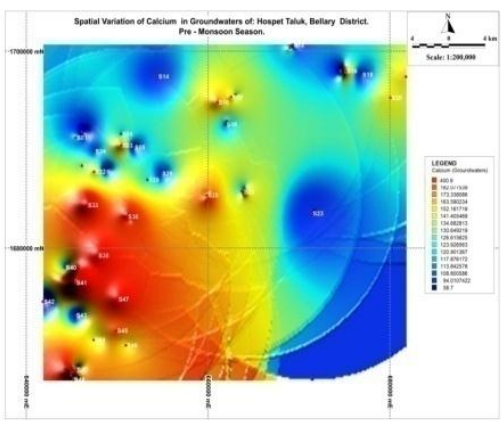

Fig. 3(a):

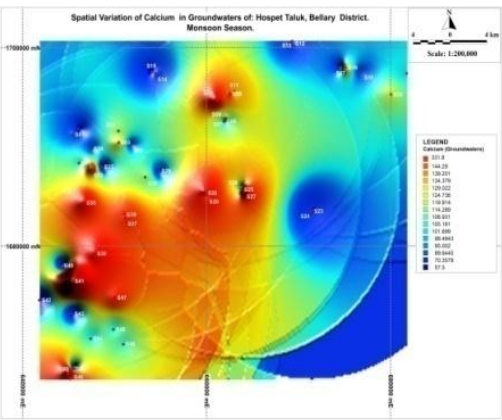

Fig. 3(a):

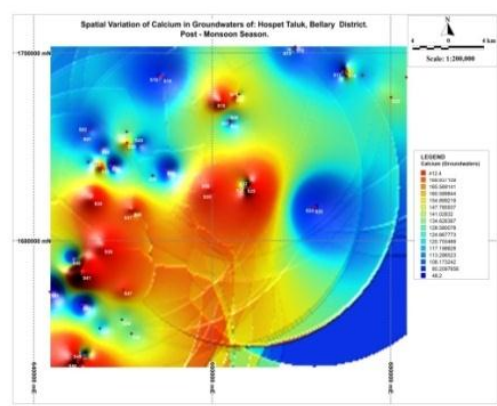

Fig. 3(a):

Average three seasons level of Ca++ (mg.L-1) at selected areas of Hospet Taluk. 
no alkali hazard to the crops is expected. 41 Location (82\%) samples come under the C3-S1 category and this category is fit for irrigational needs.

In the pre-monsoon and post-monsoon seasons, only 01 and 03 samples had the highest SAR. Irrigation water affects permeability on shrinking types in clay-type soils if the SAR is $>6$ to 9 (Karuppannan \& Kawo 2018). Overall in the entire study period, SAR value percentage comes under C2-S1 during pre-monsoon (60\%), monsoon (70\%), and post-monsoon $(50 \%)$ periods respectively. The source of salt in water can be introduced to the water either manually or by natural processes such as the weathering of rocks when the water permeates through them. EC or TDS are commonly used to calculate SH hazards. When the EC is increased, the amount of water available to the crops is reduced, leading to a deficit and low crop yield.

Sodium adsorption ratio (SAR) is a measure of the amount of sodium $\left(\mathrm{Na}^{+}\right)$relative to calcium $\left(\mathrm{Ca}^{++}\right)$and magnesium $\left(\mathrm{Mg}^{++}\right)$in the water extract from saturated soil paste (Kesari et al. 2016). It gives the sodicity of the soil through quantitative chemical assessment of water in contact with it.
According to Richards (1954), categorization of SAR values is: $<10$ (Low sodium in water, little danger), 10 to 18 (affects the texture of the soil as the soil is sensitive to $\mathrm{Na}^{+}$), 18 to 26 (maximum $\mathrm{Na}^{+}$; affects the entire soil), and $>26$ (unsatisfactory and high sodium). As per the classification, SAR values in the study area varied from 4.86 meq. $\mathrm{L}^{-1}$ in HW-41 (M.M.Halli near Anjinappa home) to 48.82 meq. $\mathrm{L}^{-1}$ in HW-34 (Hosapete near Chittavadigeppa temple) during the post-monsoon period, and in the monsoon period, SAR values varied between 4.07 meq. $\mathrm{L}^{-1}$ in HW-41 (M.M.Halli near Anjinappa home) to 17.82 meq. $\mathrm{L}^{-1}$ in HW-2 (Hosuru Near Railway gate). During pre-monsoon season SAR values varied from 0.64 meq. $\mathrm{L}^{-1}$ in HW-35 (Kallahalli near Vysyanakeri Station) to 8.82 meq.L ${ }^{-1}$ in HW-05 (Kamalapura Opp to Vet. Hospital). SAR values of three periods were shown in decreasing order: pre-monsoon (48.82 meq. $\mathrm{L}^{-1}$ ) > monsoon (17.82 meq.. $\mathrm{L}^{-1}$ ) > post-monsoon season $\left(8.82 \mathrm{meq} . \mathrm{L}^{-1}\right)$. Seasonal distribution of values of groundwater samples predicts a relatively low minimum value of SAR in the post-monsoon period, and hence, the samples can be used for irrigation on almost any soil type and have only a slight risk of sodium permeating in the soil (Bozdag 2015 \& Shammi et al. 2016).

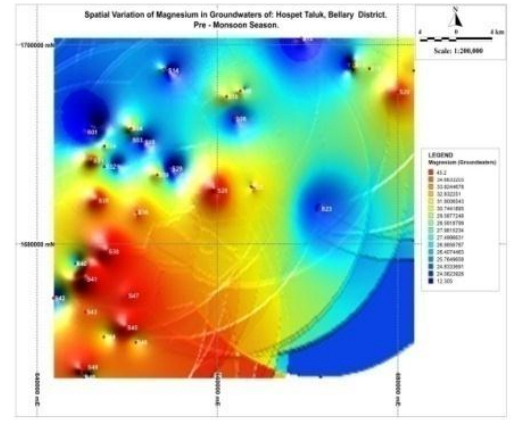

Fig. 4(a):

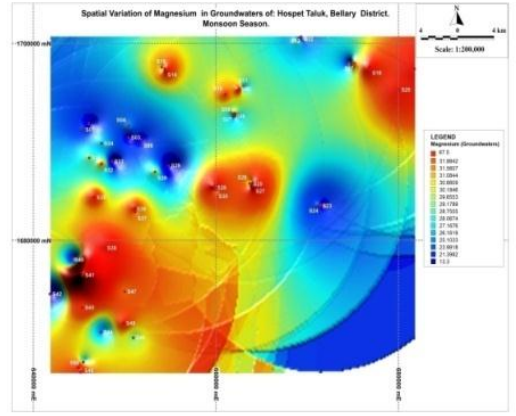

Fig. 4(a):

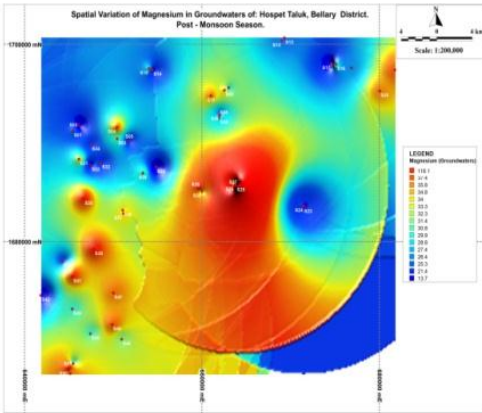

Fig. 4(a):

Average three seasons level of $\mathrm{Mg}++(\mathrm{mg} / \mathrm{L})$ at Selected Areas of Hospet Taluk.

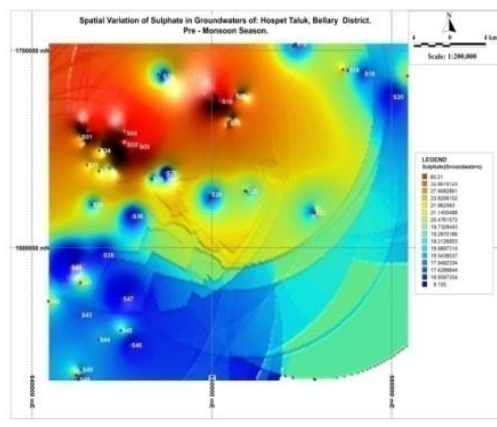

Fig. 5(a):

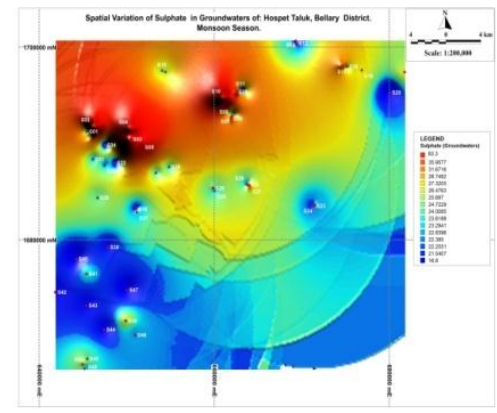

Fig. 5(a):

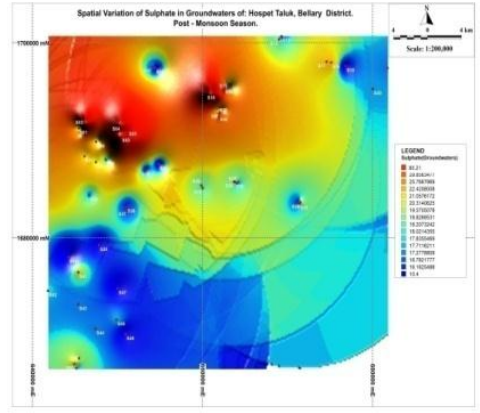

Fig. 5(a):

Average three season level of SO42- (mg/L) at Selected Areas of Hospet Taluk. 
According to SAR, the samples from the study area were classified as having a medium level of risk of sodium in the soil. If the SAR values are more than 10 and 26, the irrigation water permeability reduces in clayey soil, causing plant and soil degradation (Bozdag et al. 2015). The higher the SAR values in the water, the higher the sodium (Vasanthavigar et al. 2016).

Seasonal observation during the post-monsoon period shows that $18 \%$ of the groundwater samples fall under the good category, and $82 \%$ of groundwater samples fall under the excellent category. In the pre-monsoon period, all the samples fall under the excellent category. During the monsoon season, $8 \%$ of the groundwater samples fall under the good category, $92 \%$ of the groundwater samples fall under the excellent category. However, none of the groundwater samples are within the permissible, doubtful, and unsuitable categories. This may be because of agricultural activities. Based on Na\% (Table 2 and 3), all the groundwater samples $<20$ falls under the excellent to good Class-I irrigation water. Table 3 shows the suitability of irrigation water based on $\mathrm{Na}^{+} \%$.

Excess of $\mathrm{Mg}^{++}$in the soil effects easily the crop yield. In three periods $\mathrm{Mg}^{++}$value is more than the permissible limit except for one location. In the pre-monsoon period, the groundwater samples have a minimum value of 14.71 meq. $\mathrm{L}^{-1}$ in HW-50 (Chilakanahatti near AjathaNagalinga Mata) and a maximum value of 40.25 meq. $\mathrm{L}^{-1}$ in HW-48 (Chilakanahatti near Thimmalapura). During the monsoon season, the groundwater samples have a maximum value of 41.30 meq.L L $^{-1}$ in HW-43 (D.N.Keri, Devalapura near Shayari Durugamma Temple) and a minimum value of 14.67 meq. L $^{-1}$ in HW-50 (Chilakanahatti near AjathaNagalinga Mata), and in the post-monsoon period, the groundwater samples have a maximum value of 43.41 meq.L $\mathrm{L}^{-1}$ in HW-43 (D.N.Keri, Devalapura near Shayari Durugamma Temple) and a minimum value of 16.60 meq. $\mathrm{L}^{-1}$ in HW-50 (Chilakanahatti near AjathaNagalinga Mata). The spatial allocation of $\mathrm{MH}$ in groundwater shows that almost all the samples are within the

Table 2: SAR values for the selected groundwater samples in Hospet Taluk during three seasons.

\begin{tabular}{|c|c|c|c|c|c|c|c|c|c|c|c|c|c|}
\hline & HW-1 & HW-2 & HW-3 & HW-4 & HW-5 & HW-6 & HW-7 & HW-8 & HW-9 & $\begin{array}{l}\mathrm{H} \mathrm{W}- \\
10\end{array}$ & HW-11 & $\begin{array}{l}\mathrm{H} \text { W - } \\
12\end{array}$ & HW-13 \\
\hline Pre & 2.396 & 1.821 & 6.399 & 1.491 & 8.820 & 1.453 & 7.155 & 7.177 & 5.103 & 5.195 & 6.772 & 4.918 & 4.691 \\
\hline $\begin{array}{l}\text { Mon- } \\
\text { soon }\end{array}$ & 12.612 & 17.179 & 5.495 & 5.952 & 6.406 & 12.200 & 15.897 & 8.560 & 7.012 & 6.151 & 8.905 & 15.517 & 7.171 \\
\hline \multirow[t]{2}{*}{ Post } & 12.996 & 16.393 & 5.909 & 6.164 & 6.669 & 12.539 & 15.781 & 9.076 & 6.963 & 6.007 & 9.488 & 15.868 & 7.607 \\
\hline & $\begin{array}{l}\text { HW- } \\
14\end{array}$ & $\begin{array}{l}\text { H W - } \\
15\end{array}$ & HW-16 & HW-17 & $\begin{array}{l}\mathrm{H} \text { W - } \\
18\end{array}$ & HW-19 & HW-20 & HW-21 & HW-22 & $\begin{array}{l}\mathrm{H} \mathrm{W}- \\
23\end{array}$ & HW-24 & $\begin{array}{l}\mathrm{H} W- \\
25\end{array}$ & HW-26 \\
\hline Pre & 5.897 & 2.267 & 1.425 & 1.854 & 1.089 & 1.335 & 3.160 & 1.985 & 2.130 & 2.357 & 4.365 & 6.985 & 6.250 \\
\hline $\begin{array}{l}\text { Mon- } \\
\text { soon }\end{array}$ & 8.627 & 9.721 & 8.640 & 11.185 & 9.797 & 7.163 & 6.584 & 8.052 & 8.974 & 9.828 & 11.321 & 11.785 & 9.173 \\
\hline \multirow[t]{2}{*}{ Post } & 9.104 & 9.889 & 8.605 & 13.140 & 9.501 & 7.387 & 7.077 & 8.178 & 8.814 & 10.449 & 12.421 & 12.452 & 9.482 \\
\hline & $\begin{array}{l}\text { HW- } \\
27\end{array}$ & $\begin{array}{l}\text { H W - } \\
28\end{array}$ & HW-29 & HW-30 & $\begin{array}{l}\mathrm{H} W- \\
31\end{array}$ & HW-32 & HW-33 & HW-34 & HW-35 & $\begin{array}{l}\mathrm{H} \text { W - } \\
36\end{array}$ & HW-37 & $\begin{array}{l}\mathrm{H} \text { W - } \\
38\end{array}$ & HW-39 \\
\hline Pre & 4.328 & 1.729 & 1.799 & 1.469 & 1.058 & 0.806 & 1.747 & 1.942 & 0.644 & 1.138 & 1.350 & 0.801 & 1.663 \\
\hline $\begin{array}{l}\text { Mon- } \\
\text { soon }\end{array}$ & 8.547 & 7.010 & 9.332 & 5.081 & 6.687 & 5.950 & 7.205 & 11.328 & 9.090 & 6.511 & 6.929 & 12.100 & 8.851 \\
\hline \multirow[t]{5}{*}{ Post } & 5.102 & 6.863 & 9.758 & 5.681 & 7.912 & 6.029 & 8.172 & 18.823 & 6.207 & 7.039 & 6.928 & 12.656 & 8.773 \\
\hline & & $\begin{array}{l}\text { H W - } \\
40\end{array}$ & HW-41 & HW-42 & $\begin{array}{l}\mathrm{H} W- \\
43\end{array}$ & HW-44 & HW-45 & HW-46 & HW-47 & $\begin{array}{l}\mathrm{H} \text { W - } \\
48\end{array}$ & HW-49 & $\begin{array}{l}\mathrm{H} \text { W - } \\
50\end{array}$ & \\
\hline & Pre & 4.838 & 2.559 & 8.042 & 5.634 & 3.711 & 1.296 & 3.086 & 4.057 & 1.013 & 0.940 & 4.838 & \\
\hline & $\begin{array}{l}\text { Mon- } \\
\text { soon }\end{array}$ & 8.783 & 4.074 & 8.162 & 7.381 & 8.263 & 5.430 & 5.017 & 4.882 & 5.531 & 6.471 & 8.783 & \\
\hline & Post & 9.907 & 4.156 & 9.294 & 9.005 & 8.330 & 5.520 & 5.668 & 5.407 & 5.363 & 8.178 & 5.115 & \\
\hline
\end{tabular}


Table 3: Suitability of irrigation water based on $\mathrm{Na} \%$.

\begin{tabular}{|c|c|c|c|c|c|}
\hline \multirow[t]{2}{*}{ Parameters } & \multirow[t]{2}{*}{ Range } & \multirow{2}{*}{$\begin{array}{l}\text { Classifica- } \\
\text { tion }\end{array}$} & \multicolumn{3}{|c|}{ Number of Samples } \\
\hline & & & Pre-Monsoon & Monsoon & Post- Monsoon \\
\hline \multirow[t]{5}{*}{$\begin{array}{l}\% \mathrm{Na}^{+} \mathrm{Wil}- \\
\operatorname{cox} 1955\end{array}$} & $<20$ & Excellent & $\begin{array}{l}\text { All most all the } \\
\text { groundwater lo- } \\
\text { cations }\end{array}$ & $\begin{array}{l}\text { HW-1, HW-3, HW-10, HW-11, HW- } \\
\text { 13, HW-14, HW-15, HW-16, HW-18, } \\
\text { HW-19, HW-20, HW-21, HW-22, } \\
\text { HW-23, HW-24, HW-25, HW-26, } \\
\text { HW-27, HW-28, HW-29, HW-30, } \\
\text { HW-31, HW-32, HW-33, HW-34, HW- } \\
\text { 35, HW-36, HW-37, HW-38, HW-39, } \\
\text { HW-40, HW-41, HW-42, HW-43, HW- } \\
\text { 44, HW-45, HW-46, HW-47, HW-48, } \\
\text { HW-49, HW-50 }\end{array}$ & $\begin{array}{l}\text { HW-3, HW-4, HW-5, HW-6, HW-8, HW-9, } \\
\text { HW-10, HW-11, HW-13, HW-14, HW-15, } \\
\text { HW-16, HW-18, HW-19, HW-20, HW-21, } \\
\text { HW-22, HW-23, HW-26, HW-27, HW-28, } \\
\text { HW-29, HW-30, HW-31, HW-32, HW-33, } \\
\text { HW-35, HW-36, HW-37, HW-38, HW-39, } \\
\text { HW-40, HW-41, HW-43, HW-44, HW-45, } \\
\text { HW-46, HW-47, HW-48, HW-49, HW-50 }\end{array}$ \\
\hline & $20-40$ & Good & - & HW-2, HW-7, HW-12, HW-17 & $\begin{array}{l}\text { HW-1, HW-2, HW-7, HW-12, HW-17, HW- } \\
\text { 24, HW-25, HW-34, HW-42 }\end{array}$ \\
\hline & $40-60$ & Permissible & - & - & - \\
\hline & $60-80$ & Doubtful & - & - & - \\
\hline & $>80$ & Unsuitable & - & - & - \\
\hline
\end{tabular}

range of 50 meq. $\mathrm{L}^{-1}$ and are fit for irrigation. The maximum magnesium ratio value of the observed samples is 43.41 meq.L. $\mathrm{L}^{-1}$ in HW-43 at D.N.Keri, Devalapura near Shayari Durugamma Temple) on magnesium ratio.

The MH values of the study area range from 14.67 at HW-50 (Chilakanahatti near Ajatha Nagalinga Mata) to 43.41 meq.L ${ }^{-1}$ at HW-43 (D.N.Keri, Devalapura near Shayari
Durugamma Temple) with a mean value of 32.06). Almost all the groundwater samples (100\%) are within magnesium hazard of 50 which are considered beneficial and fit for irrigation use. In the present work, Gibbs ratio I (Anion) values in the pre-monsoon period vary from 0.05 to 0.40 , in the monsoon period varies from 0.05 to 0.42 , and in the post-monsoon period varies from 0.06 to 0.42 . Gibbs ratio
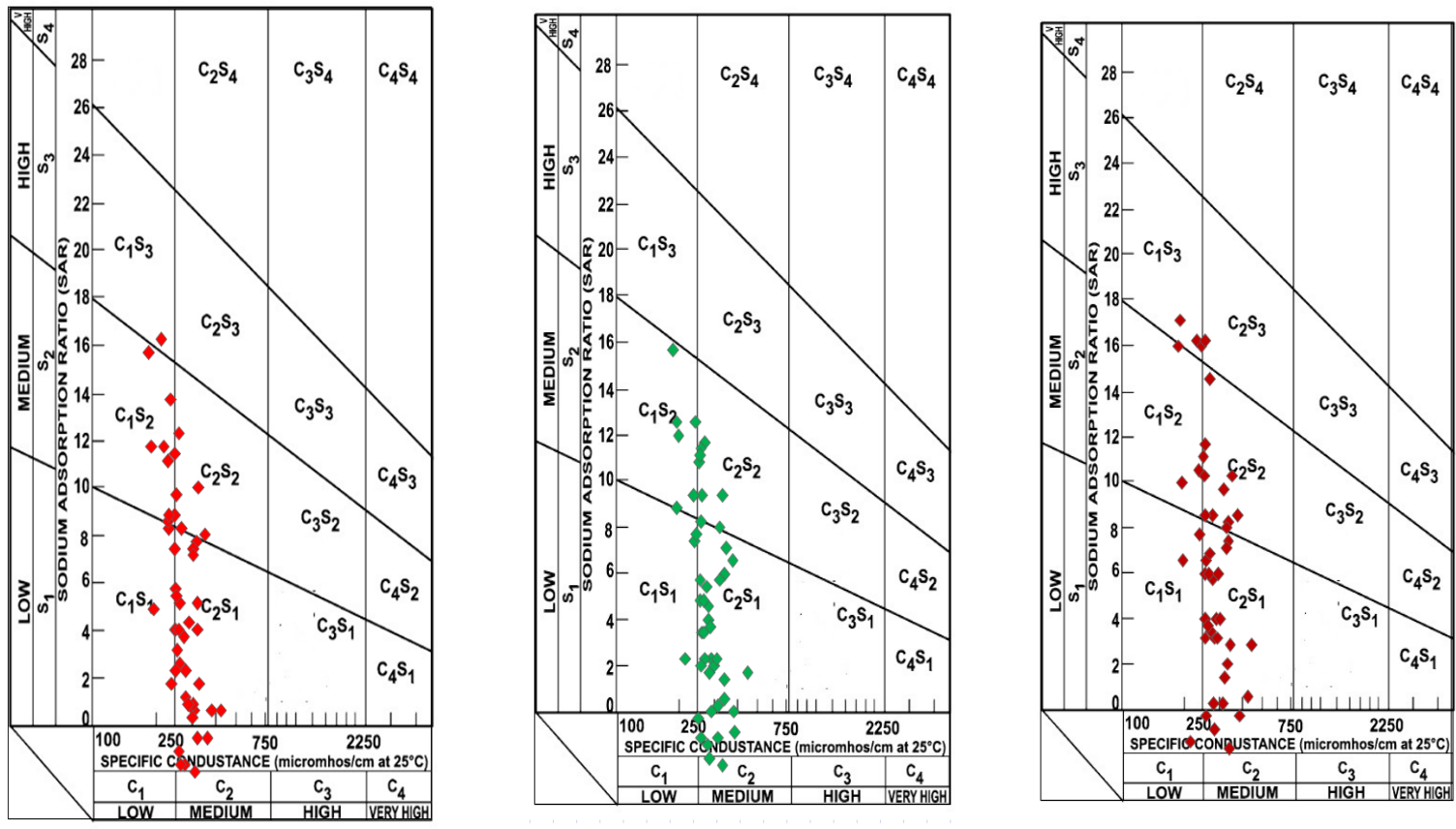

Fig. 6: SH classification of the groundwater locations according to the USSL diagram for pre- and post-monsoon and monsoon seasons. 

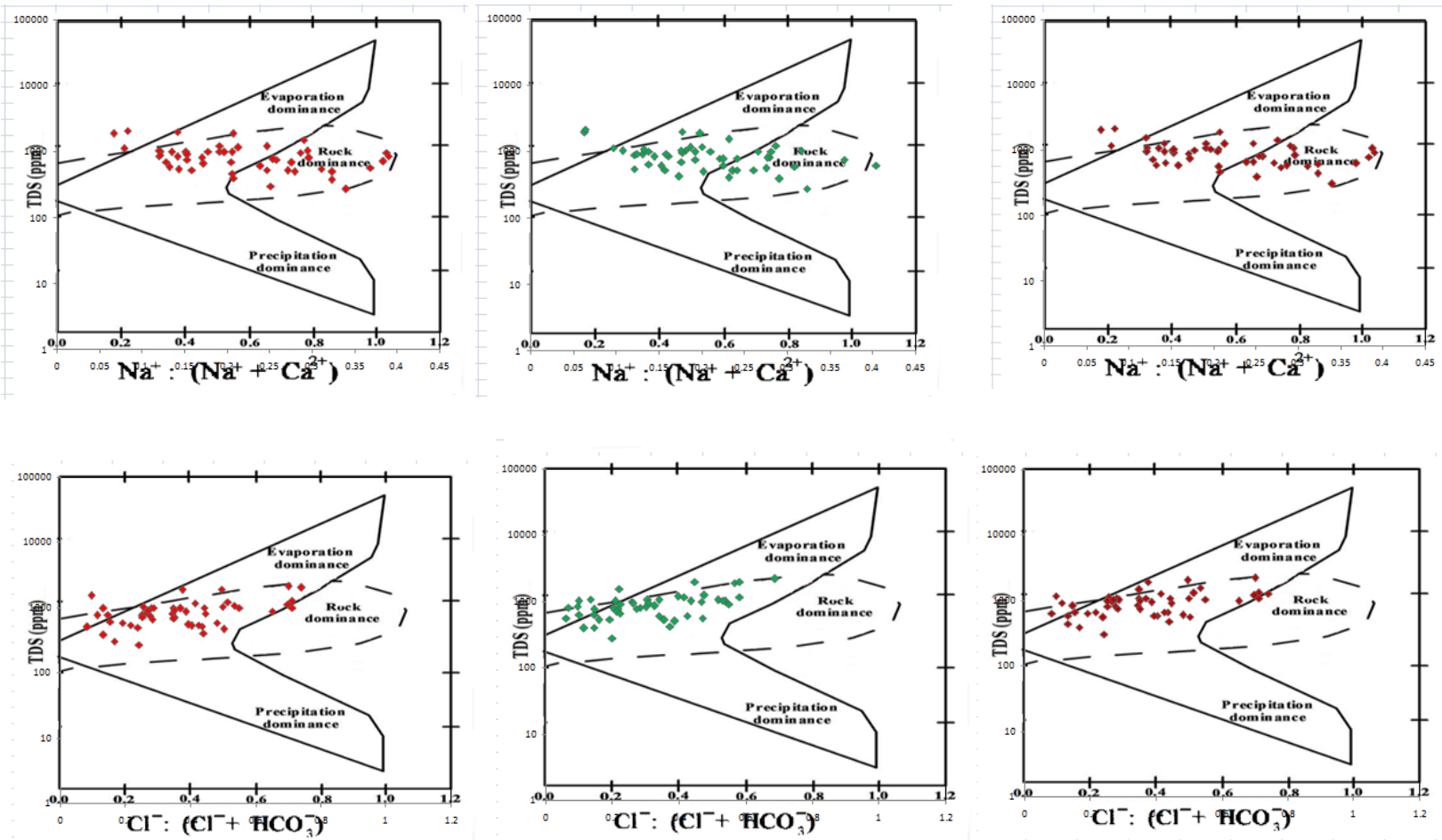

Fig. 7: Seasonal variations in mechanism controlling the quality of groundwater.

II (Cation) values vary from 0.12 to $0.78,0.11$ to 0.72 , and 0.21 to 0.81 during three seasons respectively According to Fig. 7, the samples in the study area fall into the rock dominance area, indicating rocks in the groundwater in the aquifers. This affects the hydrochemistry of groundwater in alluvial plains and rock-water contact (Wu et al. 2015).

\section{CONCLUSION}

Most of the selected locations had TH content within the permissible limit. The results showed the order of $\mathrm{Cl}^{-}>\mathrm{SO}_{4}{ }^{2-}$ $>\mathrm{HCO}^{3-}$ with water types $\mathrm{Na}_{-} \mathrm{Cl}^{-}$and $\mathrm{Cl}^{-}$, and the order of $\mathrm{Na}^{+}>\mathrm{Mg}^{++}>\mathrm{Ca}^{++}>\mathrm{K}^{+}$with $\mathrm{Na}^{+}$and $\mathrm{Mg}^{++}$as the dominant anions and cations, correspondgly. As per the Wilcox diagram no-alkali exposure to the crops is expected. Forty one samples $(82 \%)$ fit within the $\mathrm{C} 3-\mathrm{S} 1$ group; this category is fit for irrigational needs. Only 01 and 03 samples showed maximum SAR during two seasons like pre-monsoon and post-monsoon periods. The GIS maps of the respective variables indicated that groundwater are usually of higher quality, whereas the presence of dolomite indicates a reduction in water quality.

\section{REFERENCES}

Adiat, K.A.N., Nawawi, M.N.M. and Abdullah, K. 2012. Assessing the accuracy of GIS-based elementary multicriteria decision analysis as a spatial prediction tool: A case of predicting potential zones of sustainable groundwater resources. J. Hydrol., 440-441: 75-89.

APHA. 2005 Standard Methods for the Examination of Water and Wastewater. 21st Edition, American Public Health Association/American Water Works Association/Water Environment Federation, Washington DC.

Asante-Annor, A., Bewil, P.N. and Boateng, D. 2018. Evaluation of groundwater suitability for irrigation in the Lambussie-Karni district of Ghana. Ghana Mining J., 18(1): 9-19.

Bozdag, A. 2015. Combining AHP with GIS for assessment of irrigation water quality in Cumra irrigation district (Konya), Central Anatolia, Turkey. Environ. Earth Sci., 73: 8217-8236.

Champidi, P., Stamatis, G. and Zagana, E. 2011. Groundwater quality assessment and geogenic and anthropogenic effect estimation in Erasinos Basin (E. Attica). European Water, 33: 11-27.

Elubid, A.B., Tao Huang, T., Ekhlas, H., Ahmed, E.H., Zhao, J., Elhag, K.M., Abbass, W. and Babiker, M.M. 2019. Geospatial distributions of groundwater quality in Gedaref State using geographic information system (GIS) and drinking water quality index (DWQI). Int. J. Environ. Res. Public Health, 16(5): 2-20.

EPA. 2009. The United States Environmental Protection Agency. http:// www.epa.gov/ogwdw000/kids/wsb/pdfs/9124.pdf. Accessed on 30 December 2009.

Freeze, R.A. and Cherry, J.A. 1979. Groundwater. Prentice-Hall, Upper Saddle River.

Hemant, P. and Limaye, S. N. 2012. Assessment of physico-chemical quality of groundwater in a rural area nearby Sagar city, MP, India. Adv. Appl. Sci. Res., 3(1); 555-562.

Honarbakhsh, A., Tahmoures, M., Tashayo, B., Mousazadeh, M., Ingram, B., and Ostovari, Y. 2019. GIS-based assessment of groundwater quality for drinking purposes in the northern part of Fars Province, Marvdasht. J. Water Supply: Res. T-Aqua., 68(3): 187-196 
Kawo, N.S. and Karuppannan, S. 2018. Groundwater quality assessment using water quality index and GIS technique in Modjo River Basin, Central Ethiopia. J. Afr. Earth Sci., 147: 300-311.

Kesari, T., Ramakumar, K.L., Chidambaram, S., Pethperumal, S. and Thilagavathi, R. 2016. Understanding the hydro-chemical behavior of groundwater and its suitability for drinking and agricultural purposes in Pondicherry area, South India: A step towards sustainable development. Groundwater Sustain. Dev., 2-3: 143-153.

Madan, K.J., Chowdary, V.M. and Chowdhury, A. 2010. Groundwater assessment in Salboni Block, West Bengal (India) using remote sensing, geographical information system, and multi-criteria decision analysis techniques. Hydrogeol. J., 18(7): 1713-1728.

Mallick, J., Singh, C.K., Al Wadi, H., Ahmed, M., Rahman, A., Shashtri, S. and Mukherjee S. 2015. Geospatial and geostatistical approach for groundwater potential zone delineation. Hydrol. Process., 10: 153.

Mukherjee, P., Singh, C.K. and Mukherjee, S. 2012. Delineation of groundwater potential zones in the arid region of India: A remote sensing and GIS approach. Water Resour. Manag., 26(9): 2643-2672

Pujari, P.R., Padmakar, C., Labhasetwar, P.K., Mahore, P. and Ganguly, A.K. 2012. Assessment of the impact of on-site sanitation systems on groundwater pollution in two diverse geological settings: A case study from India. Environ. Monit. Assess., 184(1): 251-263.
Richards, L.A. 1954. Diagnosis and Improvement of Saline Alkali Soils. Agriculture, 160, Handbook 60, US Department of Agriculture, Washington DC.

Shammi, M., Karmakar, B., Rahman M.M., Islam, M.S., Rahman, R. and Uddin M.K. 2016 Assessment of salinity hazard of irrigation water quality in the monsoon season of Batiaghata Upazila, Khulna District, Bangladesh, and adaptation strategies. Pollution, 2: 183-197.

Swarna Latha, P. 2010. Studies on spatial and temporal changes of land use and land cover groundwater quality and shoreline of greater Vishakapatanum municipal corporation, Andrpradesh, India using remote sensing and GIS techniques. Ph.D, thesis, Andra University, Vishakapatanum.

Vasanthavigar, M., Srinivasamoorthy, K., Rajiv Gandhi, R., Vijayaraghavan, K. and Sarma, L.S. 2016. Characterization and quality assessment of groundwater with a special emphasis on irrigation utility: Thirumanimuttar sub-basin, Tamil Nadu, India. Arab. J. Geosci., 5(2): 245-258.

Verma, A.K. and Singh, T.N. 2013 Prediction of water quality from simple field parameters. Environ. Earth Sci., 69(3): 821-829.

Wu, J., Li, P. and Qian, H. 2015 Hydrochemical characterization of drinking groundwater with special reference to fluoride in an arid area of China and the control of aquifer leakage on its concentrations. Environ. Earth Sci., 73: 8575-8588. 